\title{
Abrupt Change in Sahara Precipitation and the Associated Circulation Patterns
}

\author{
Celestin Sindikubwabo', Ruolin $\mathrm{Li}^{2}$, Chenghai Wang1 \\ ${ }^{1}$ Key Laboratory of Arid Climate Change and Disaster Reduction of Gansu Province, College of Atmospheric Sciences, Lanzhou \\ University, Lanzhou, China \\ ${ }^{2}$ The Northwest Institute of Eco-Environment and Resources, Chinese Academy of Sciences (CAS), Lanzhou, China \\ Email:wch@lzu.edu.cn, sicel11@hotmail.com
}

How to cite this paper: Sindikubwabo, C., Li, R.L. and Wang, C.H. (2018) Abrupt Change in Sahara Precipitation and the Associated Circulation Patterns. Atmospheric and Climate Sciences, 8, 262-273. https://doi.org/10.4236/acs.2018.82017

Received: March 19, 2018

Accepted: April 27, 2018

Published: April 30, 2018

Copyright (C) 2018 by authors and Scientific Research Publishing Inc. This work is licensed under the Creative Commons Attribution International License (CC BY 4.0).

http://creativecommons.org/licenses/by/4.0/

\begin{abstract}
This study investigates the changes in inter-annual summer precipitation and the relationship with the atmospheric general circulation in the Sahara Desert occurred in the last 40 years (1971-2010). The results show that the summer precipitation undergone in drought recovery with a strong abrupt change at the end of $20^{\text {th }}$ century. This change in Sahara precipitation is subsequently accompanied with the changes in the atmospheric circulation. The Sahara drought recovery is associated with a significant warming in the tropical and extratropical sea surface temperature, which led to the increase in moisture budget of the tropical African monsoon. The remarkable features such as the strengthening in Arctic high and mid-latitude upper level westerly wind, weakening in subpolar low and upper tropospheric zonal wind over North Africa have shown a distinct relationship with the Sahara precipitation changes.
\end{abstract}

\section{Keywords}

Drought, Recovery, North Africa, Sahara, Desert, Trend, Climate

\section{Introduction}

The global climate change threats and stresses daily risks to the human activities, and the lack of information is main cause of these risks [1]. The abrupt climate change may lead to the unpredicted risks. The simple definition of abrupt climate change signifies the large and faster change to reach the breaking point of climate in a given period [2]. The arid and semi-arid regions are vulnerable to the climate change as well as remaining part of the globe; it is reported that the equatorward expansion of the Sahara desert in the last 60 ka exposed the current 
relict dune in Sahel region and associated with the variability of sea surface temperature (SST) over North Atlantic (NA) and atmospheric dust loading [3].

Not only the arid climate in the Sahara Desert but also the entire climate of Africa continent in general is most vulnerable to the global change [4]. Different studies show that the annual mean rainfall isolines range between $25 \mathrm{~mm}$ per year and $50 \mathrm{~mm}$ per year, which defines the Sahara Desert to be an extremely arid region [5] [6] [7]. The spatial distribution of the Sahara precipitation presents the relatively high annual precipitation in the western part, and the lowest annual rainfall appears in the eastern in the range of $1 \mathrm{~mm}$ to $5 \mathrm{~mm}$ per year [8]. However, the current Sahara Desert is completely hot and dry, but reconstructed climatic models shown that, around 4000 years B.C this region was green than current situation[9]. This green Sahara was suggested by palaeobotanical evidence that disappeared in Pliocene and revealed the cooling and aridification in North Africa [9] [10]. It has been suggested that the mid-Holocene green Sahara problem implied substantial differences in rainfall patterns presumably related to the change in summer monsoon circulation [10] [11]. However, almost eighteen paleoclimate models show that the increases in monsoon magnitude over north Africa are underestimated [11].

The changes in temperature are also one of the most evident and easily detected changes in climate, and the atmospheric circulation, water vapour and rainfall also change when the whole climate system is affected [12]. The aforementioned changes alter the hydrological cycle particularly type, amount, frequency, characteristics, and intensity of precipitation and extremes such as flood and drought which are prone to be increase owing to the global warming [12] [13].

Response of regional climate to global warming has received much attention in previous years. The Fifth Assessment Report (AR5) reported on the drying period over tropical land areas from mid-1970s to mid-1990s and subsequent increase in precipitation [14]. The AR5 through the Representative Concentration Pathways (RCP) projected that, the precipitation in most areas of Africa would be stable, but the annual precipitation in Central and Eastern Africa would increase [15]. AR5 also shows that the global precipitation trend recovery is tied to an anthropogenic forcing, particularly in the northern latitudes [15]. Moreover, the annual precipitation over North Africa, particularly in the Atlas Mountains and the Mediterranean climate zone will experience the decreasing trend in mid and late $21^{\text {st }}$ century for RCP 8.5 [16].

Based on satellite data, an investigation on seasonal and year-to-year precipitation in Sahara Desert shows that, the year to year precipitation is characterized by different features including mainly the two distinct (dry and wet) seasons separated by a short transition period [17]. The dry period occurs during boreal winter and is characterized by a relatively high precipitation but concentrated in the northern part of Sahara under influence of Mediterranean winter period while the summer season reveals a prominent amount of precipitation relatively 
concentrated in the southern part of Sahara with tropical rainfall dependence [17]. This study conclude that the prevailing of mid-latitude jet stream enhances the winter precipitation, while the African Easterly Jet (AEJ) and lower layer moisture both subjected to the West African monsoon (WAM), affect summer rainfall. The transition period results from the changes in rainfall types (i.e. the change from extratropical to tropical rainfall types) is related to the changes in moisture and zonal wind in the Northern Hemisphere (NH) [17]. However, the previous studies strived to understand the characteristics of Sahara Desert precipitation and its connection to general circulation but the variability on the large time scale and the climate change nexus need further research. Thus, this study focused on the long-term variability in the Sahara precipitation and its relationship to the climate change including an existence of an abrupt change and the changes in atmospheric general circulation as the root of recent increase in Sahara precipitation observed in the last four decades of 1971-2010. This will lead to the further understanding of the characteristics of spatial and temporal variability of Sahara precipitation and significantly improve our understanding of from global change responses to the regional climates changes. It will also enhance our understanding to the role of climate change in arid regions particularly, the vulnerability of hyper-arid climate.

The remaining sections are organised as follows. Section 2 provides a brief description of data and methods. Section 3 presents the Spatial and temporal variability of the Sahara precipitation. Section 4 examines the drought recovery and its relationship to the general circulation anomalies. Section 5 provides the conclusion and discussions.

\section{Data Description and Methodology}

The representative observation data are adopted from the seventh version of the Global Precipitation Climatology Centre (GPCC) [18]. Full data provided by the GPCC reveals conformity with in situ precipitation data set sampled for GPCC interpolation which leads the GPCC reanalysis to be compatible with climate monitoring on reginal-scale, model evaluation and validation, analysis of climate variability and the water resource studies and related assessment researches [18].

The gridded monthly precipitation values over Sahara Desert are weighted and forty years summer precipitation anomalies are calculated with respect of the thirty years (1981-2010) climatological mean. The precipitation anomalies are expressed in percentage (\%) and calculated through the Equation (1) shown below

$$
P_{i}=\frac{x_{i}-\bar{x}}{\bar{x}} \times 100
$$

where $P_{i}$ and $x_{i}$ define the precipitation anomaly and average of the summer precipitation for each year $i$ since 1971-2010, respectively. The $\bar{x}$ stands for thirty years (1981-2010) climatological mean of summer precipitation.

This study adopted and applied the Mann Kendall test statistics [19] [20], to 
detect the existence of abrupt change in Sahara precipitation. For a given time series $x_{t}$ the test detects approximate significant abrupt point through the ranking method. The generated ranking values $y_{t}$ with the magnitude of $y_{t}(t=1,2,3,4, \cdots, n)$ from observations are compared with $y_{k}(k=1,2,3,4, \cdots, t-1)$ and result in $S_{t}$ counted if $y_{t}>y_{k}$. This leads to compute a statistical test $A_{t}$ as follows;

$$
A_{t}=\sum_{k=1}^{t} S_{t}
$$

And the mean of test statistic $A_{t}$ is calculated as;

$$
M\left(A_{t}\right)=\frac{t(t-1)}{4}
$$

With the variance of

$$
\delta\left(A_{t}\right)=\frac{t(t-1)(2 t+5)}{72}
$$

A standardized variable $U\left(A_{t}\right)$ is sequentially computed

$$
U\left(A_{t}\right)=\frac{A_{t}-M\left(A_{t}\right)}{\sqrt{\delta\left(A_{t}\right)}}
$$

The forward sequential statistic $U\left(A_{t}\right)$ and denoted $U_{f}$ is computed using observational times series and the back forward $U^{\prime}\left(A_{t}\right)$ denoted $U_{b}$ is also estimated using the inverse time series. An abrupt point is simply detected at the intersection point of $U_{f}$ and $U_{b}$ and it is significant if it occurs between $0 \pm$ $1.96[19]$.

\section{Spatial and Temporal Variability of the Sahara Precipitation}

Africa is characterised with a large diversity of precipitation types with a distinct shift between them [5]. North Africa particularly the Sahara Desert is affected by Mediterranean climate with a significantly high (low) winter (summer) precipitation and a tropical climate dominated with boreal summer monsoons and dry winters [5] [17] [21].

The changes in monthly precipitation illustrate that in the last 40 years, the Sahara precipitation has conserve an obvious seasonal features, Although the magnitude of precipitation in Sahara Desert is not large, but the variability has a significant role to the large number of its habitant population. Figure 1 shows a mean precipitation calculated from GPCC monthly total of precipitation. It is evident that the precipitation distribution in Sahara Desert is highly sparse and weak in magnitude particularly in the central and eastern part of the Sahara Desert.

The spatial distribution Figure 1(a) depicts an average of annual precipitation calculated from 40 years monthly precipitation. It shows that, the Sahara precipitation is relatively contracted in the West but less than $100 \mathrm{~mm}$ per year while the eastern part of the Sahara Desert present a permanent dry seasons with rare 

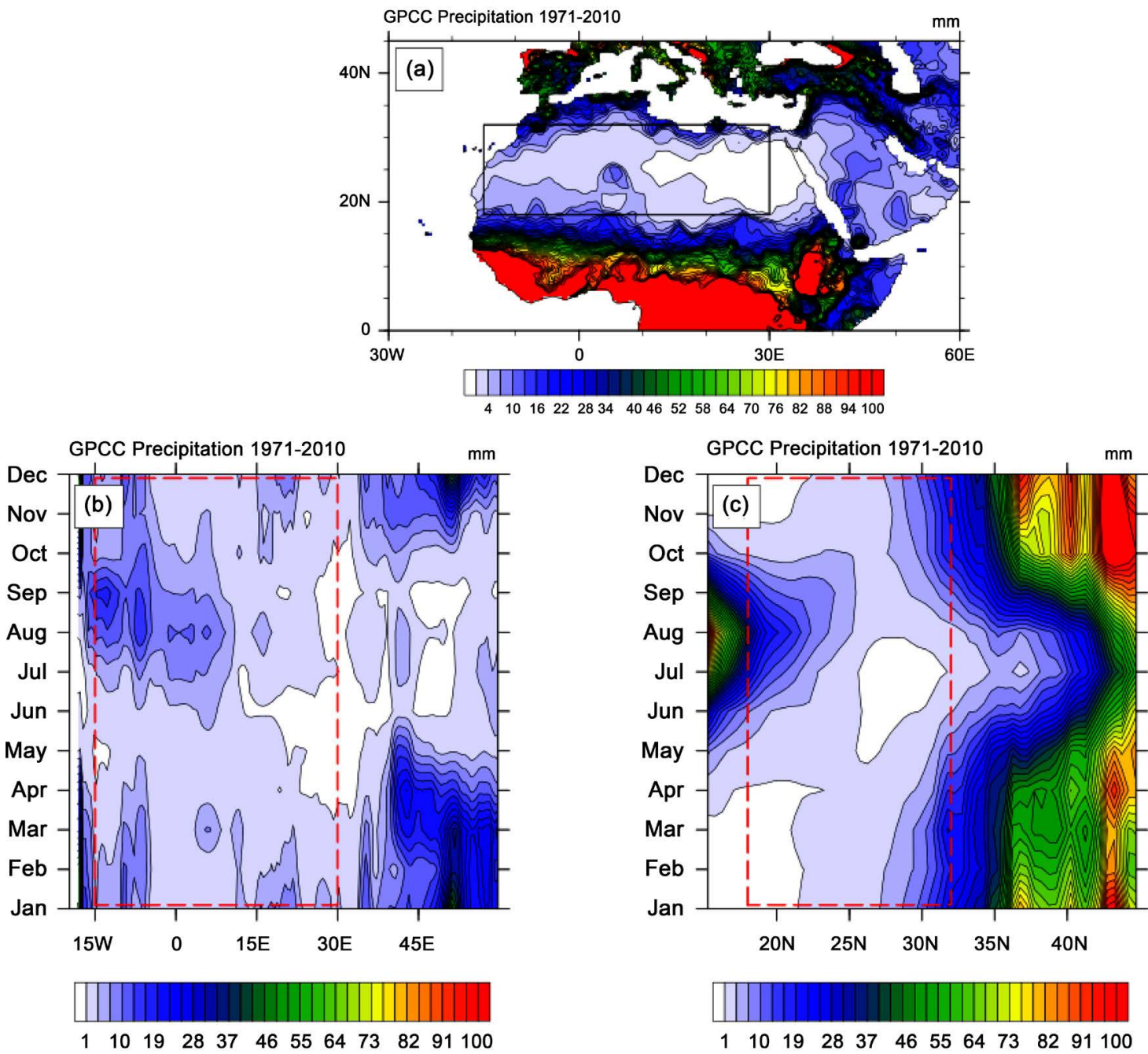

Figure 1. Spatial distribution (a) annual mean precipitation, (b) longitudinal and (c) latitudinal mean of monthly precipitation for each month of 40 years 1971-2010. Boxes represent the area of study.

precipitation varies under $5 \mathrm{~mm}$ per year. This result is consistent with the previous research on precipitation over Sahara Desert and it has shown that, the East Sahara Desert receives the lowest annual precipitation [8] [17]. The eastern low precipitation distribution extends to Central Asian in Arabian Desert and Northwest China.

Figure 1(b) \& Figure 1(c) affirm the aforementioned precipitation distribution and show the mean of monthly precipitation for each month of 40 years. Longitudinal and latitudinal annual precipitation cycle reveals that, a relatively high precipitation is concentrated in the months of July, August and September, here considered as the summer season. This indicates that the variation in productivity of the rainfed agriculture are prone the variability of the summer precipitation. Therefore, this study focuses on the changes occurred in precipitation of the Sahara Desert during July, August and September (JAS) of the past 40 years, 1970-2010.

To examine the changes in the Sahara Desert precipitation, the Figure 2 shows 


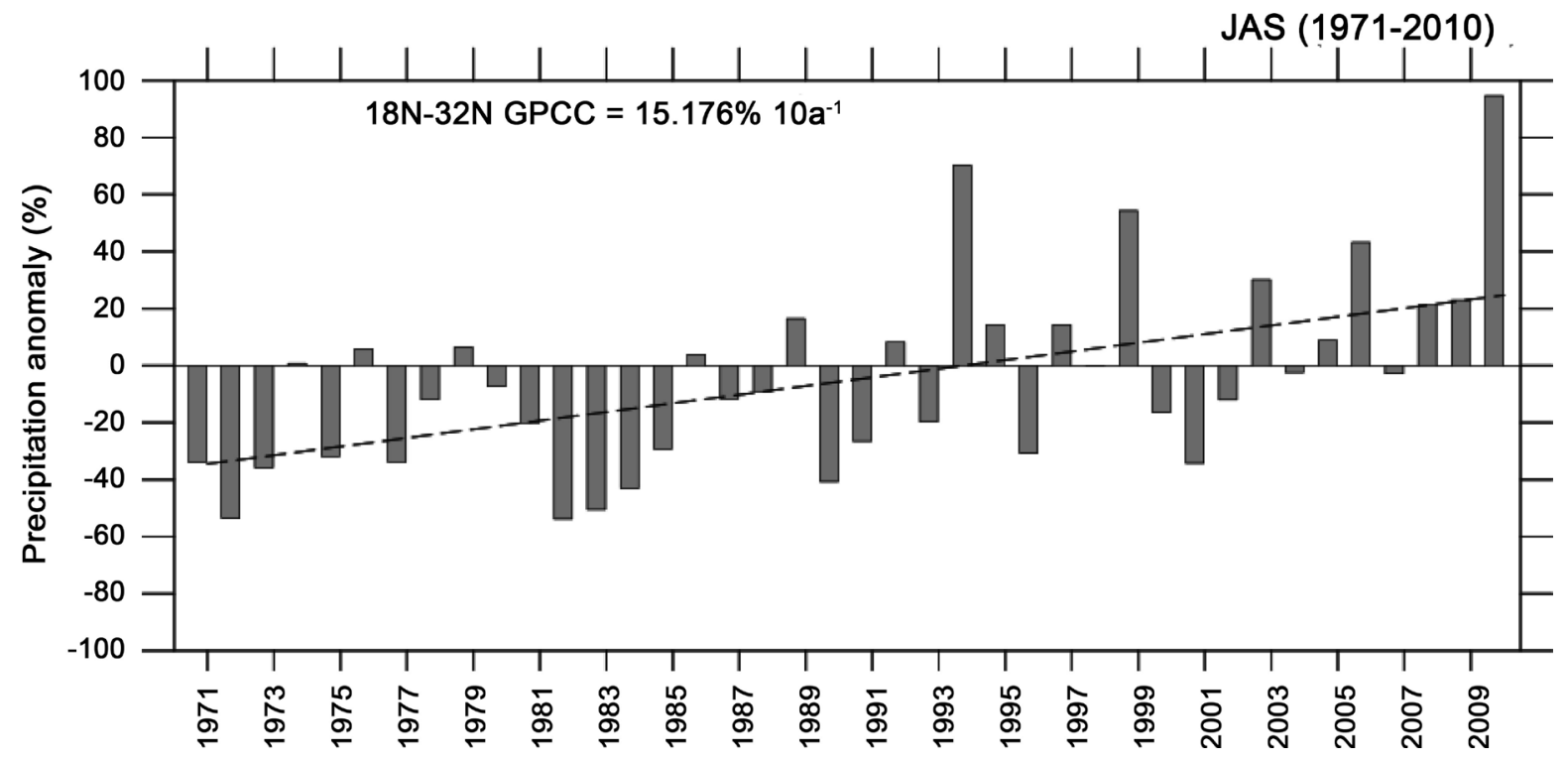

Figure 2. Temporal variation of inter-annual summer precipitation anomaly (\%) within 1971-2010.

the evolution of summer precipitation anomaly (\%) in the last four decades (1971-2010). The result shows that the Sahara Desert has experienced a long drought from 1971 to 1993 and a recovery afterward. In the late 1990s to 2010, the precipitation over Sahara Desert showed an obvious recovery with an increasing trend of $15.2 \%$ par decade (pass the $95 \%$ level of significance). The temporal variability of precipitation in the Sahara Desert presents similarities with the global precipitation anomaly, which implies that, the Sahara precipitation has been affected by anthropogenic forcing responsible to the global precipitation change [22].

\section{Sahara Drought Recovery}

The temporal variability of the Sahara precipitation shows an unusual extreme precipitation in the middle of the 1990s. This led us to test an existence of abrupt change in the Sahara precipitation. Figure 3 shows that, the Sahara Desert has experienced a significant abrupt change in the middle of 1990s followed by an increase in precipitation. The significant abrupt changes are observed in the summer precipitation of 1992 and the 1993. This period is remarkably followed by frequent extremes in precipitation as revealed by the temporal precipitation variability in Figure 2.

Moreover, the previous researches have evaluated paleoclimate of the Sahara Desert and have shown that, the Sahara Desert has experienced the long record of abrupt changes from wet to dry climate attributed to the different changes in climate variables mostly tied to the migration in summer rainfall [23]-[31]. The simulation of global climate models have concluded with an abrupt vegetation and precipitation collapses during mid-Holocene induced by an extreme insolation forcing [27].

The disappearance of the green Sahara dominated by the hydrological fluctuation 


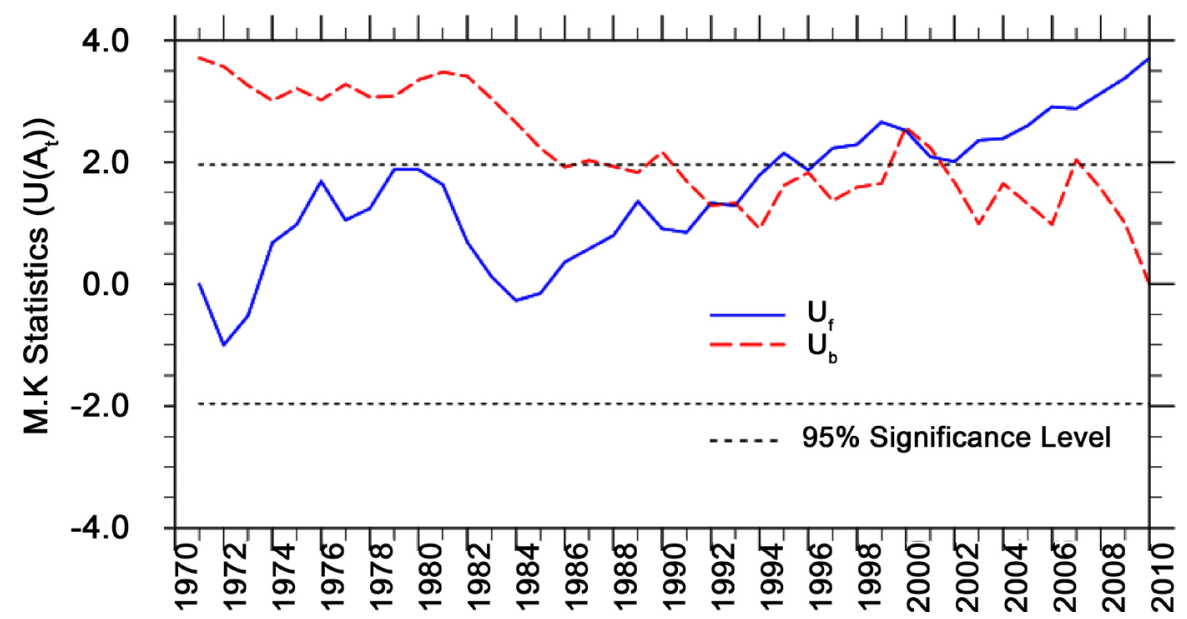

Figure 3. Abrupt change in JAS precipitation as calculated from sequential Mann-Kendall statistical test.

and associated with the changes in tropical summer monsoon [24]. The tropical rainfall has experienced an extreme drought particularly Sahel precipitation and it has been suggested that the Sahel drought is prone to equatorward shift of the continental rainbelt and the changes in anticyclonic circulation linked to the warming in Indian Ocean [32] [33]. The model simulations shown that, the late $19^{\text {th }}$ century arid rainfall recovery is real but present the frequent multiyear oscillation [34].

To further understand the role of the general circulation to the Sahara precipitation recovery, the composite analysis in $\mathrm{SST}, \mathrm{SH}(925 \mathrm{hPa})$ geopotential height $(500 \mathrm{hPa})$ and zonal wind $(200 \mathrm{hPa})$ have been employed.The circulation changes patterns between period of abundance in and low precipitation anomalies are evaluated. The temporal variability of inter-annual summer precipitation anomaly (Figure 2) is adopted to define the period of dry and wet years. Thus, the dry periods is defined by annual precipitation anomaly less than $40 \%$ which includes the year of 1972, 1982, 1983 and 1984 while the wet period observed after abrupt change is defined by annual precipitation anomaly greater than $40 \%$ and includes the years of 1994, 2009, 2006 and 2010.

Figure 4 depicts the patterns resulted from the difference between the mean summer general circulation components of wet and dry period. In the upper troposphere, the zonal wind of $200 \mathrm{hPa}$ shows obvious wave-like patterns with a pronounced decrease in tropical upper tropospheric troughs, which extends eastwardly to the Eastern Sahara. The increase in Sahara precipitation period also has encountered with the increase in tropical and extratropical zonal wind. The statistically significant test shows that the period with a relatively high precipitation is dominated with a strong extratropical upper zonal wind which lies over the North Atlantic Ocean and extends to west coast of Europe. Meanwhile the Guinean Gulf is dominated with the increase in zonal wind and shown a poleward penetration. Thus, the increase in precipitation is subjected to variation in tropical and extratropical upper level winds. 

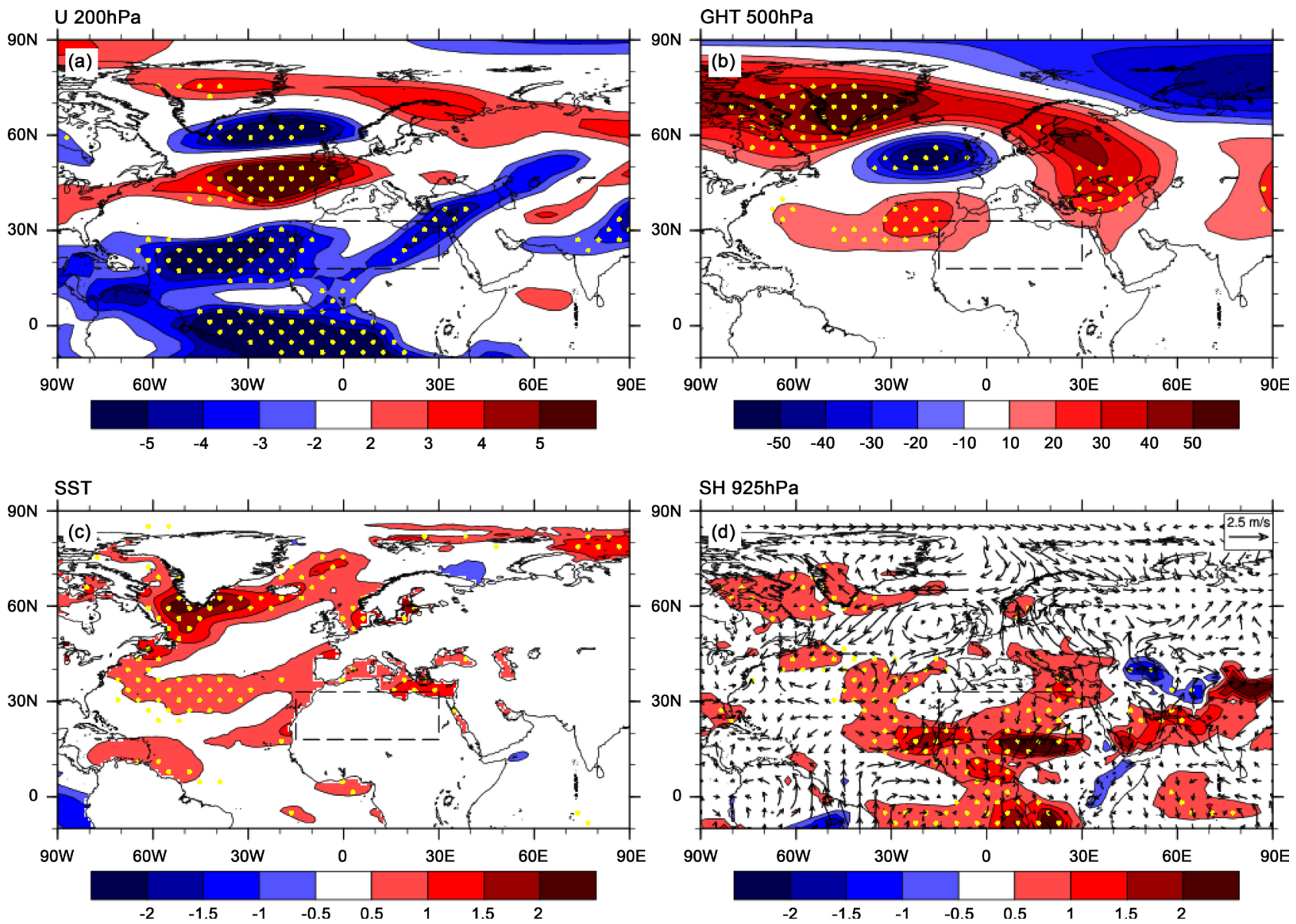

Figure 4. Composites in atmospheric general circulation (a) zonal wind of $200 \mathrm{hPa}$, (b) geopotential height of $500 \mathrm{hPa}$, (c) sea surface temperature and (d) specific humidity (color) of $925 \mathrm{hPa}$ with wind divergence (arrows) of $925 \mathrm{hPa}$ and t-test with $>95 \%$ level of significance (Dots).

The increase in Sahara precipitation is also significantly related with an increase in geopotential height over Greenland region. The increase in mid-tropospheric geopotential height has been linked with recent global warming, which led to ice sheet melting [35]. This warming in Arctic is accompanied with a significant weakening and strengthening in geospatial height of boreal subpolar lows and Azores high, respectively. Thus, we can conclude that, the shrinking in Greenland ice sheet and increase in Azores high include in responsible factors of observed abrupt change and afterward increase in the Sahara precipitation. Moreover, Arctic warming is revealed by an increase of North Atlantic SSTs with temperature difference exceeds $2^{\circ} \mathrm{C}$ in the southern Greenland. SSTs warming extend to East coast of North America and the central Atlantic to Mediterranean Sea. Tropical North Atlantic has also warmed, the raise in SST is distributes from Caribbean Gulf to the Western Sahara coast. This warming in SSTs is consistent with the model simulations results, which reported that, the Sahel drought recovery is prone the warming in extratropical SSTs including recent warming of the Sahara heat low [36] [37].

Raise in Atlantic and Mediterranean SSTs are responsible to the increase in 
North Africa dependent moisture. Figure 4(c) \& Figure 4(d), the distinct patterns observed in SSTs and humidity variabilities are remarkable correspondent over Mediterranean, Greenland and the Azores high regions. The Guinean Gulf has also shown a strong increase in convective moisture, which leads to the persistence of wet period in West Africa, meanwhile an entire African monsoon region, affirmed its large contribution to the recent Sahara wet period. The wind vectors have drawn the northward penetration of African monsoon moisture and the strengthening (weakening) in subpolar low (subtropical high), respectively.

\section{Conclusions}

This study investigated an abrupt change occurred in Sahara precipitation and the contribution of general circulation during the last four decades 1971-2010. Although, the magnitude in the Sahara annual precipitation is low, the variability of arid precipitation conserves a tremendous effect on the sustainability of regional agriculture and oasis eco-environment [38] [39] [40] [41]. Thus, this study leads to the following conclusions

- Sahara precipitation has shown a significant seasonal variability features dominated with a relatively high in summer and early autumn precipitation. In the last four decades, the Sahara precipitation shows an increase and significant trend of $15.2 \% / 10 \mathrm{a}$

- The summer precipitation in the Sahara Desert has experienced a remarkable drought event from 1971 to the early 1990s, which should be related to the decrease in global precipitation occurred during 1950 to late 1980s [12] and the drought occurred in Sahel [21]

- The early 1990s to 2010 presents a dramatic drought recovery accompanied with an abrupt change occurred in the period between 1992 and 1993 (Figure 3). This change resulted in positive trend of $18 \%$ per decade while the period of 1971-1991 shows a positive trend of only 5\%/10a, but trends are not statistically significant.

- Abrupt change occurred in Sahara summer precipitation is tied to the warming in North Atlantic and Mediterranean Sea SSTs which trigged the African tropical moisture and to the increase in moisture budget in the southern part of the Sahara Desert. Moreover, the changes in middle tropospheric general circulation components reflected through the increase in subpolar low and subtropical high over the North Atlantic region and the change in the upper level zonal wind have also shown a great contribution to an occurred abrupt change and the increase of the Sahara precipitation.

\section{Acknowledgements}

We highly acknowledge the National Science Foundation of China (No. 41471034, No.91437217, and No.41661144017), Industry Special Projects of CMA (GYHY201506001, CCSF2014) to support this work. 


\section{References}

[1] IPCC (2014) Climate Change 2014: Mitigation of Climate Change. http://www.ipcc.ch/report/ar5/wg3/

[2] Rahmstorf, S. (2001) Abrupt Climate Change. In: Encyclopedia of Ocean Sciences, Elsevier, 1-6. https://doi.org/10.1006/rwos.2001.0269

[3] Collins, J.A., Govin, A., Mulitza, S., Heslop, D., Zabel, M., Hartmann, J., et al. (2013) Abrupt Shifts of the Sahara-Sahel Boundary during Heinrich Stadials. Climate of the Past, 9, 1181-1191. https://doi.org/10.5194/cp-9-1181-2013

[4] Boko, M., Niang, I., Nyong, A., Vogel, C., Githeko, A., Medany, M., Osman-Elasha, B., Tabo, R. and Yanda, P. (2007) Africa. In: Parry, M.L., Canziani, O.F., Palutikof, J.P., Linden, P.J. van der and Hanson, C.E., Eds., 2007. Climate Change 2007: Impacts, Adaptation and Vulnerability. Contribution of Working Group II to the Fourth Assessment Report of the Intergovernmental Panel on Climate Change (IPCC). Cambridge University Press, Cambridge, UK, 433-467.

[5] Liebmann, B., Bladé, I., Kiladis, G.N., Carvalho, L.M.V., Senay, G.B., Allured, D., et al. (2012) Seasonality of African Precipitation from 1996 to 2009. Journal of Climate, 25, 4304-4322. https://doi.org/10.1175/JCLI-D-11-00157.1

[6] Nicholson, S.E. (2000) The Nature of Rainfall Variability over Africa on Time Scales of Decades to Millenia. Global and Planetary Change, 26, 137-158. https://doi.org/10.1016/S0921-8181(00)00040-0

[7] Liu, P., Washington, W.M., Meehl, G.A., Wu, G. and Potter, G.L. (2001) Historical and Future Trends of the Sahara Desert. Geophysical Research Letters, 28, 2683-2686. https://doi.org/10.1029/2001GL012883

[8] Kelley, O.A. (2014) Where the Least Rainfall Occurs in the Sahara Desert, the TRMM Radar Reveals a Different Pattern of Rainfall Each Season. Journal of Climate, 27, 6919-6939. https://doi.org/10.1175/JCLI-D-14-00145.1

[9] Micheels, A., Eronen, J. and Mosbrugger, V. (2009) The Late Miocene Climate Response to a Modern Sahara Desert. Global and Planetary Change, 67, 193-204. https://doi.org/10.1016/j.gloplacha.2009.02.005

[10] Hales, K., Neelin, J.D. and Zeng, N. (2006) Interaction of Vegetation and Atmospheric Dynamical Mechanisms in the Mid-Holocene African Monsoon. Journal of Climate, 19, 4105-4120. https://doi.org/10.1175/JCLI3833.1

[11] Joussaume, S., Taylor, K.E., Braconnot, P., Mitchell, J.F.B., Kutzbach, J.E., Harrison, S.P., et al. (1999) Monsoon Changes for 6000 Years Ago: Results of 18 Simulations from the Paleoclimate Modeling Intercomparison Project (PMIP). Geophysical Research Letters, 26, 859-862. https://doi.org/10.1029/1999GL900126

[12] Trenberth, K.E. and Josey, S.A. (2007) Observations: Surface and Atmospheric Climate Change. In, Solomon, S., Qin, D., Manning, M., Chen, Z., Marquis, M., Averyt, K.B., Tignor, M. and Miller, H.L., Eds., Climate Change 2007: The Physical Science Basis. Contribution of Working Group I to the 4th Assessment Report of the Intergovernmental Panel on Climate Change, Cambridge University Press, Cambridge, 235-336.

[13] Trenberth, K.E., Dai, A., Rasmussen, R.M. and Parsons, D.B. (2003) The Changing Character of Precipitation. Bulletin of the American Meteorological Society, 84, 1205-1217. https://doi.org/10.1175/BAMS-84-9-1205

[14] Hartmann, D.J., Klein Tank, A.M.G., Rusticucci, M., Alexander, L.V., Brönnimann, S., Charabi, Y.A.-R., et al. (2013) Observations: Atmosphere and Surface. In: Climate Change 2013: The Physical Science Basis Contribution of Working Group I to 
the 5th Assessment Report of the Intergovernmental Panel on Climate Change, Cambridge University Press, Cambridge, 159-254.

[15] Bindoff, N., Stott, P., AchutaRao, K., Allen, M., Gillett, N., Gutzler, D., et al. (2013) Detection and Attribution of Climate Change: From Global to Regional. In: Climate Change 2013: The Physical Science Basis Contribution of Working Group I to the 5 th Assessment Report of the Intergovernmental Panel on Climate Change, Cambridge University Press, Cambridge, 867-952.

[16] Niang, I., Ruppel, O.C., Abdrabo, M.A., Essel, A., Lennard, C., Padgham, J., et al. (2014) Africa. In: Barros, V.R., Field, C.B., Dokken, D.J., Mastrandrea, M.D. and Mach, K.J., Eds., Climate Change 2014: Impacts, Adaptation and Vulnerability, Cambridge University Press, Cambridge, 1199-1266.

[17] Harada, C., Sumi, A. and Ohmori, H. (2003) Seasonal and Year-to-Year Variations of Rainfall in the Sahara Desert Region Based on TRMM PR Data. Geophysical Research Letters, 30, 1288. https://doi.org/10.1029/2002GL016695

[18] Schneider, U., Becker, A., Finger, P., Meyer-Christoffer, A., Rudolf, B. and Ziese, M. (2015) GPCC Full Data Reanalysis Version 7.0 at 0.5: Monthly Land-Surface Precipitation from Rain-Gauges Built on GTS-Based and Historic Data. Global Precipitation Climatology Centre, 1-13.

[19] Ahmad, I., Tang, D., Wang, T., Wang, M. and Wagan, B. (2015) Precipitation Trends over Time Using Mann-Kendall and Spearman's Rho Tests in Swat River Basin, Pakistan. Advances in Meteorology, 2015, 1-15. https://doi.org/10.1155/2015/431860

[20] Safari, B. (2012) Trend Analysis of the Mean Annual Temperature in Rwanda during the Last Fifty Two Years. Journal of Environmental Protection, 3, 538-551. https://doi.org/10.4236/jep.2012.36065

[21] Nicholson, S.E. (1981) Rainfall and Atmospheric Circulation during Drought Periods and Wetter Years in West Africa. Monthly Weather Review, 109, 2191-2208. https://doi.org/10.1175/1520-0493(1981)109<2191:RAACDD>2.0.CO;2

[22] IPCC (2014) Climate Change 2014 Synthesis Report Summary Chapter for Policymakers. IPCC, 31.

[23] Claussen, M., Brovkin, V., Ganopolski, A., Kubatzki, C. and Petoukhov, V. (2003) Climate Change in Northern Africa: The Past Is Not the Future. Climatic Change, 57, 99-118. https://doi.org/10.1023/A:1022115604225

[24] Castaneda, I.S., Mulitza, S., Schefuss, E., Lopes dos Santos, R.A., Sinninghe Damste, J.S. and Schouten, S. (2009) Wet Phases in the Sahara/Sahel Region and Human Migration Patterns in North Africa. Proceedings of the National Academy of Sciences, 106, 20159-20163. https://doi.org/10.1073/pnas.0905771106

[25] Foley, J.A., Coe, M.T., Scheffer, M. and Wang, G. (2003) Regime Shifts in the Sahara and Sahel: Interactions between Ecological and Climatic Systems in Northern Africa. Ecosystems, 6, 524-539. https://doi.org/10.1007/s10021-002-0227-0

[26] Kuper, R. (2006) After 5000 BC: The Libyan Desert in Transition. Comptes Rendus Palevol, 5, 409-419. https://doi.org/10.1016/j.crpv.2005.10.013

[27] Liu, Z., Wang, Y., Gallimore, R., Notaro, M. and Prentice, I.C. (2006) On the Cause of Abrupt Vegetation Collapse in North Africa during the Holocene: Climate Variability vs. Vegetation Feedback. Geophysical Research Letters, 33, L22709. https://doi.org/10.1029/2006GL028062

[28] Lézine, A.-M., Hély, C., Grenier, C., Braconnot, P. and Krinner, G. (2011) Sahara and Sahel Vulnerability to Climate Changes, Lessons from Holocene Hydrological 
Data. Quaternary Science Reviews, 30, 3001-3012. https://doi.org/10.1016/j.quascirev.2011.07.006

[29] Schulz, E. (1991) Holocene Environments in the Central Sahara. Hydrobiologia, 214, 359-365. https://doi.org/10.1007/BF00050971

[30] Rachmayani, R., Prange, M. and Schulz, M. (2015) North African Vegetation-Precipitation Feedback in Early and Mid-Holocene Climate Simulations with CCSM3-DGVM. Climate of the Past, 11, 175-185. https://doi.org/10.5194/cp-11-175-2015

[31] Bubenzer, O. and Reimer, H. (2007) Holocene Climatic Change and Human Settlement between the Central Sahara and the Nile Valley: Archaeological and Geomorphological Results. Geoarchaeology, 22, 607-620.

https://doi.org/10.1002/gea.20176

[32] Caminade, C. and Terray, L. (2010) Twentieth Century Sahel Rainfall Variability as Simulated by the ARPEGE AGCM, and Future Changes. Climate Dynamics, 35, 75-94. https://doi.org/10.1007/s00382-009-0545-4

[33] Hagos, S.M., Cook, K.H., Hagos, S.M. and Cook, K.H. (2008) Ocean Warming and Late-Twentieth-Century Sahel Drought and Recovery. Journal of Climate, 21, 3797-3814. https://doi.org/10.1175/2008JCLI2055.1

[34] Dai, A., Lamb, P.J., Trenberth, K.E., Hulme, M., Jones, P.D. and Xie, P. (2004) Comment the Recent Sahel Drought Is Real. International Journal of Climatology, 24, 1323-1331. https://doi.org/10.1002/joc.1083

[35] Fettweis, X., Mabille, G., Erpicum, M., Nicolay, S. and van den Broeke, M. (2011) The 1958-2009 Greenland Ice Sheet Surface Melt and the Mid-Tropospheric Atmospheric Circulation. Climate Dynamics, 36, 139-159. https://doi.org/10.1007/s00382-010-0772-8

[36] Park, J.Y., Bader, J. and Matei, D. (2015) Northern-Hemispheric Differential Warming Is the Key to Understanding the Discrepancies in the Projected Sahel Rainfall. Nature Communications, 6, 5985. https://doi.org/10.1038/ncomms6985

[37] Evan, A.T., Flamant, C., Lavaysse, C., Kocha, C. and Saci, A. (2015) Water Vapor-Forced Greenhouse Warming over the Sahara Desert and the Recent Recovery from the Sahelian Drought. Journal of Climate, 28, 108-123. https://doi.org/10.1175/JCLI-D-14-00039.1

[38] Liu, H., Chen, W., Dong, X. and Zhang, X. (2009) Sustainable Agricultural Paradigm of Mountain-Oasis-Ecotone-Desert System in Inland Manasi River Basin, Xinjiang Province, Northwest China. International Conference on Computer and Computing Technologies in Agriculture, Beijing, 14-17 October 2009, 197-207. https://doi.org/10.1007/978-1-4419-0209-2_22

[39] Wang, S., Zhang, M., Che, Y., Chen, F. and Qiang, F. (2016) Contribution of Recycled Moisture to Precipitation in Oases of Arid Central Asia: A Stable Isotope Approach. Water Resources Research, 52, 3246-3257. https://doi.org/10.1002/2015WR018135

[40] Li, B.F., Chen, Y.N., Shi, X., Chen, Z.S. and Li, W.H. (2013) Temperature and Precipitation Changes in Different Environments in the Arid Region of Northwest China. Theoretical and Applied Climatology, 112, 589-596. https://doi.org/10.1007/s00704-012-0753-4

[41] Li, C.-S., Yang, X.-H., Zhang, K.-B., Yu, C.-T. and Ci, L.-J. (2007) Response Characteristics of Precipitation, Soil Moisture and Groundwater Level in Desert-Oasis System. Journal of Beijing Forestry University, 29, 129-135. 